\title{
Untold Stories of Jamaican Canadian Immigrant Women: Building Resilience Through Faith
}

\author{
Sandra P. Dixon \\ University of Lethbridge \\ sandra.dixon@uleth.ca
}

\begin{abstract}
In this article, attention is given to the key role that Pentecostal faith plays in the cultural identity reconstruction process of some Jamaican Canadian immigrant women. For many immigrant groups, religious faith represents an anchor of hope for coping with post-migration life stressors. Although, once emotionally caged in a new socio-cultural location in Canada, the women portrayed in this summary of my research demonstrate great fortitude and endurance in navigating a new cultural and socio-historical context. Their untold stories of resilience through religious faith led them to deeper critical awareness, scholarly accountability, and recognition of their truths.
\end{abstract}

Keywords: Resilience, Jamaican Canadian immigrant women, Pentecostal faith, cultural identity

"Strong women of faith, that's who we are; Overcoming the brutality of slavery to find freedom in the revolution of our spiritual bravery." (Dixon, 2015, p. 155)

As a Jamaican Canadian woman who immigrated to Canada as an adolescent, my personal experience of racial and cultural discrimination damaged my sense of self, but my spiritual orientation provided me with the personal agency to reconstruct that self. My spiritual faith helped me to cope with issues of racial and cultural discrimination in an environment in which I was socially dislocated. I have come to recognize through my own lived experience as an immigrant that faith, as a coping tool for Jamaican Canadian immigrants, is not represented in the social science scholarship and research. Here, I argue that faith is a personal and experiential construct that encompasses elements of religious and spiritual practices given its subjective conceptualization. Within this experiential dimension, faith can be empowering for many individuals like myself with limited socio-economic resources at their disposal to cope with postmigration challenges in a multicultural context. Thus, my passion was ignited as a doctoral student who felt caged with my own fragmented identity. My caged sense of self needed freedom to speak my truth. In so doing, I wanted to create a safe cultural space for other women to liberate their fragmented cultural identities - a broken sense of self - through their faith stories. This desire for liberation gave birth to a collective journey of cultural identity reconstruction ${ }^{1}$ through faith within a Canadian multicultural context.

\footnotetext{
${ }^{1}$ In this paper, I describe cultural identity reconstruction as the process by which an identity fragmented by postmigration stressors (e.g., racism, prejudice, etc.) is reconstructed using various coping strategies like faith (Dixon, 2019b).
}

Cultural and Pedagogical Inquiry, Summer 2020, 12(1), pp. 200-215

ISSN 1916-3460 () 2020 University of Alberta

http://ejournals.library.ualberta.ca/index.php/cpi/index 
The Caribbean has one of the largest diasporic populations in the world, if one considers the number of people who migrate with the region's total population. Data collected by the United Nations for over a decade indicate that there is an estimated 6.7 million people from the Caribbean living outside the region (Jones et al., 2014). There are approximately 5.3 million migrants from the Caribbean living in the United States (US), 756,000 migrants living in Europe, and 472,000 reside in Canada (Jones et al., 2014). By 2016, there are 749,155 immigrants of Caribbean origins living in Canada (Statistics Canada, 2017). In comparison, the current population of the Caribbean based on the latest United Nations estimates is 43,504,941 (Worldometer, n.d.).

In a larger demographic context, during the past ten to twenty years, the historical pattern of immigration to Canada has shifted considerably from traditional sources in Europe to nontraditional sources in Asia countries (including the Middle East). At present, the largest numbers of immigrants come from countries in Asia, Africa, the Caribbean, and Central and South America (Statistics Canada, 2018a). Since 2011, the three largest non-dominant ${ }^{2}$ immigrant $^{2}$ groups in Canada are as follows: South Asian, Chinese and Blacks who account for $66.3 \%$ of the non-dominant population (Statistics Canada, 2018a). According to Statistics Canada (2019), the Black $^{3}$ population has doubled in size, increasing from 573,860 persons in 1996 to 1,198,540 persons in 2016. Therefore, race overrides key socio-economic status, gender, and religious differences (Owen et al., 2014). This article concentrates on the Canadian post-migration experiences of several Jamaican Canadian immigrant women (JCIW) who live in Alberta. It presents a series of snapshots concerning the relevant theoretical frameworks from the published literature and discusses the women's lived experiences as they navigate their post-migration journey while clinging to their faith for resilience and strength. In this study, resilience describes an interplay of risk and protective processes over time, involving individual, family, and larger socio-cultural influences (Walsh, 2003). As the primary researcher in this study, I join my voice with those of the other Jamaican Canadian immigrant women (JCIW) as we share our collective lived experiences of the post-migration process.

Due to severe constraints placed on the article's length, this discussion focuses on a few key areas of the research which complement Maya Angelou's themes of caged and free birds. Hopefully, the summary in this article neither undervalues nor devalues the extensive and detailed contributions and narratives of the co-researchers ${ }^{4}$ in the larger study. The paper engenders a discussion (implicitly and explicitly) that reveals the ways in which racialized minorities may be put into cages by the assumptions, cultural identity models and analyses of research conducted by members of the dominant group in the North American context. The emerging findings of the study in question emphasized the spiritual resiliency of the co-researchers through their active participation with their Pentecostal faith. A discussion unfolds about the role of oppression in the

\footnotetext{
2 The term non-dominant refers to "those groups who are commonly marginalized in society by virtue of their differences from the dominant Anglo-Saxon, male, heterosexual culture" (Arthur \& Collins, 2010, p. 16).

${ }^{3}$ In this discussion, the term Black refers to a socio-political construct that includes English-speaking people of African and Caribbean descent (Moodley et al., 2000). These identifiers are used interchangeably within this article.

${ }^{4}$ In heuristic inquiry, the methodology used in this study, participants are referred to as co-researchers because shared meanings of narratives are co-constructed between the primary researcher and co-researchers, based on their similar experiences (Moustakas, 1990; Sela-Smith, 2002). Also, the unique and subjective nature of this qualitative approach allows for the integration of the researcher's voice and the use of the first person (Hiles, 2008). See Dixon (2015) for a detailed overview of the study's methodology and procedures namely, coresearcher's recruitment, research process, data analysis and data coding.
}

Cultural and Pedagogical Inquiry, Summer 2020, 12(1), pp. 200-215

ISSN 1916-3460 () 2020 University of Alberta

http://ejournals.library.ualberta.ca/index.php/cpi/index 
lives of JCIW. The paper concludes with further reflections about the untold stories of JCIW and their resilience through faith.

In this article, I share my journey of healing through my dissertation. I begin with a methodology section, where I provide an overview of hermeneutics, the approach I adopted for my dissertation, and heuristic inquiry, applicable to my healing journey and this article, to elucidate the significance of both methodologies in my research, as there are significant overlaps and one research approach (hermeneutics in the dissertation) triggered the other (heuristic inquiry). I then share themes of personal learning, followed by a creative synthesis of my story through the co-researchers' narratives. I conclude with the significance of research based on personal life experiences. Participants are an integral part of knowledge production, both in hermeneutics (Cohen et al., 2000) and heuristic (Moustakas, 1990) methodologies, and hence they are referred to as co-researchers.

\section{Context and Justification for the Research}

As earlier mentioned, I was motivated to undertake this study due to my socio-cultural positioning as a Jamaican Canadian woman with affiliation to the Pentecostal faith. As members of a non-dominant group, many Jamaican Canadian immigrant women like me, struggle initially, to fit into the new Canadian culture. Accordingly, we have difficulty gaining acceptance by other Canadians with whom we associate with daily. In the discourse of multiculturalism, for example, it is important to understand the experiences of JCIW who may turn to their spirituality and religion to play key roles in reconstructing their new cultural identities in this country. Accordingly, for mental health providers, ${ }^{5}$ to develop an understanding of the JCIW would be critical in order to facilitate help-seeking behaviour changes for this group (Dixon, 2019a). Yet, based on my thorough review of the social science literature (e.g., Canadian Woman Studies, Canadian Psychology Journal, Journal of Social Science, Journal of Multicultural Counselling and Development and Journal of Counselling \& Development), the roles that religious faith and spirituality play in helping Black Caribbeans adapt to a new Canadian culture has received scant attention. Evidently, Black women are considered to be more religious and spiritual than their male counterparts (Statistics Canada, 2013; Taylor et al., 2010).

Therefore, my study was conducted with Jamaican Canadian immigrant women (JCIW) to shed light of this much-needed topic. I randomly selected women from Pentecostal churches in Calgary with the intent to portray diversity in age (ranged from 27 to 53 years old), education (high school to tertiary), length of time in Canada (timeframe ranged from 1-20 years), and church membership duration (timeframe ranged from 1-36 years). The total number of coresearchers I interviewed was determined by the saturation of themes. The research study explored the co-researchers' lived experiences in the Canadian context and how Pentecostal faith played an instrumental role in the post-migration process. Further, the navigation and reconstruction of cultural identity amid post-migration stressors (e.g., systemic racism, discrimination, marginalization, and underemployment) are examined (DePass, 2012b; Dixon, 2019b). These stressors inadvertently give rise to mental health concerns such as stress, depression, and suicidal thoughts (McKenzie et al., 2011; Dixon, 2019a). This discussion on

\footnotetext{
${ }^{5}$ In this context, mental health providers include professionals in the social science sector who provide support to immigrants like counsellors, social workers, psychologists, and practitioners.
}

Cultural and Pedagogical Inquiry, Summer 2020, 12(1), pp. 200-215

ISSN 1916-3460 @ 2020 University of Alberta

http://ejournals.library.ualberta.ca/index.php/cpi/index 
JCIW of the Pentecostal faith and how they navigated the post-migration process unfolds using a social constructionist theoretical lens.

\section{Positioning the Study in a Social Constructionist Theoretical Framework}

This study adopted a social constructionist (SC) theoretical framework (Shotter, 1993). Social constructionists focus on how people use language (Burr, 2003) in cultural practices to accomplish social purposes (Edwards \& Potter, 1992). Adopting a SC lens, all knowledge is created within specific cultures and is influenced by particular social conditions within various historical time periods. As importantly, the creation of knowledge is located in daily interactions between individuals (Burr, 2003). What is even more relevant to this study is: that knowledge is seen as embedded in social practices, and therefore, to know is to know from within (Shotter, 1993). In terms of spiritual and religious practices, this sense of knowing applies to patterns of interpersonal communications and interactions. When applied to the Pentecostal faith, it means the openness and willingness to participate, perform, identify, and respond to such specific group practices like speaking in tongues and worshiping without judgement (Dixon \& Arthur, 2014, 2019). Furthermore, exploring the cultural dynamics of some JCIW who belong to the Pentecostal faith, will aid in developing our social science knowledge-base of their individual, cultural and religious worldviews. Such knowledge demands a better understanding that can likely be achieved by evaluating and critiquing cultural identity models, developed from Eurocentric worldview that tend to ignore the experiences of non-dominant groups. Cross's model (Cross, 1971, 1978) is the marked exception. As such, I will address it below given its cross-cultural applicability to the experience of JCIW.

\section{Overview of Cultural Identity Models}

Over the years, the development of cultural identity has become an area of much critique in the social sciences. The critique is due to the tendency for theorists to offer broad generalizations of models that primarily focus on racial identity to the exclusion of cultural identity frameworks. In this article, the concepts of cultural and racial identity are defined to foster a better understanding of their key premises in relation to people of African descent. Hall (1992), for example, depicted cultural identity as a multi-factorial, social construct that characterizes "those aspects of their identities which arise from their 'belonging' to distinctive ethic, racial, linguistic, religious, and above all, national cultures" (Hall 1992, p. 273). Hall's work is important because it captures a realistic representation of the lived experiences of some JCIW. Specifically, the women who encounter social and geographical dislocations postmigration. Such dislocations significantly interfered with their abilities to cope with stressors in Canada (Dixon, 2015; James \& Davis, 2012). On the other hand, racial identity embodies a social characterization of individuals based on identified or perceived physical or behavioural features (e.g., skin colour) (James, 2010).

In the social science literature, racial classification has been used as an othering tactic by the dominant White population to label non-dominant groups. Othering practices are based on social divisions associated with European colonization that resulted in intergenerational psychological trauma and oppression (Othering 101 Psychology, 2011). Through the marginalization of othering tactics, people of African descent including JCIW, have become

Cultural and Pedagogical Inquiry, Summer 2020, 12(1), pp. 200-215

ISSN 1916-3460 @ 2020 University of Alberta

http://ejournals.library.ualberta.ca/index.php/cpi/index 
classified as the "minority." Othering practices are stereotypic and systemic ways to maintain the status quo and encourage separation between ethno-cultural and racialized groups of people (Arthur \& Collins, 2010; Este et al., 2018). Racial labelling perpetuates cultural generalizations that tend to over-value the experiences of the dominant White culture and de-value the multilayered racial dynamics of non-dominant cultures like the JCIW in my study (Brown, 2017; Dixon 2019b; James \& Davis, 2012). For example, in the mainstream society, generally White women are categorized as polite, well-articulate, and innocent. In contrast, Black women are often labelled as aggressive, hostile and angry (Tulshyan, 2015).

The dearth of research conducted in the areas of racial and cultural identities is problematic for non-dominant populations because they are frequently excluded from the dominant discourse of racial inclusivity (Dixon, 2015). Further, most of the work on cultural identity has placed great emphasis on whiteness, which tends to be viewed as a homogeneous category, namely, that there is "an illusionary single white racial identity" (Moodley, 2007, p. 14). This view of whiteness portrays a skewed image of cultural identity and undermines the reality that the development of one's cultural identity signifies a universal process that all individuals become involved with at the unconscious level (Arthur \& Collins, 2010). However, in recent years, the multicultural movement has given rise to consciousness-raising in racial and cultural identity models that acknowledge non-dominant populations in North American contexts, specifically the US. The racial orientation of these models attempts to acknowledge the experience of diverse ethnic groups, such as Black Americans (Cross, 1971); Latino/Hispanic Americans (Casas \& Pytluk, 1995) and Asian Americans (Sue \& Sue, 1971).

Given the significance of cultivating a strong identity among Blacks, emphasis is given to Cross's (1971) Model, also referred to as the Nigrescence Model. This model sheds light on the stages of development of a Black cultural identity. A leading African-American theorist and scholar in the field of ethnic identity development, William E. Cross Jr., is credited for being one of the first researchers to draw attention to the earliest model of Minority Identity Development (MID) in the psychology literature (Cross, 1971, 1978). This model offers a theoretical conceptualization of Black identity development. The characteristics range from identifying lower to higher levels of racial awareness, with an emphasis on the impact of race on one's life (Cross, 1971). Cross's theory ignited the emergence of multiple racial and ethnic identity development theories and research, and continues to serve as a basis for models of MID (Richardson et al., 2010; Sullivan \& Esmail, 2012).

Initially, Cross (1971) developed a five-stage model which was later revised to a fourstage model with seven identities. The four stages are: (a) pre-encounter, (b) encounter, (c) immersion-emersion, and (d) internalization-commitment. Brief descriptions of the stages are provided below.

Pre-encounter. This stage describes two identities: assimilation and anti-black. Individuals operating from an assimilation identity tend to be "pro-American" and claim to be colour blind in their racial views. This means they have low salience concerning racial issues. In contrast, the anti-black identity describes individuals whose miseducation, disinformation, ignorance, and due to structural and systemic socio-economic factors, all inform their negative depictions of the Black community. Unfortunately, individuals at this stage exercise self-hatred towards their reference group. They seek approval from Whites by trying to overcome their 
internalized societal stigma of being Black. One might argue that these individuals might be stereotyped as the "Uncle Toms and Aunt Jemimas" within the US popular culture.

Encounter. Individuals at this stage may have experienced and personalized a significant racio-cultural event (e.g., the racism that Angelou's caged bird experiences in the poem). The impact of such an event destroys the pre-encounter identity and changes their worldview on racial issues in radical ways (Cross et al., 1991).

Immersion-Emersion. Cognitive dissonance occurs at this stage, where individuals experience mental conflicts in trying to adopt a new worldview while obliterating their old identity. Two identities emerge at this stage: (i) intense black involvement and (ii) being antiwhite. Intense black involvement embraces Black cultural norms, while people with an anti-white identity denigrate White people and White culture.

Internalization. This stage consists of three distinctive identities: (i) Black nationalist, (ii) bi-culturalist, and (iii) multi-culturalist. Individuals with the Black nationalist identity focus on Black community empowerment. The biculturalist identity characterizes two key elements, namely self-acceptance and pluralist perspectives that consist of other dimensions, like gender and sexual orientation. Lastly, the multi-culturalist identity focuses on multiple identities.

Cross's $(1971,1978)$ model offers a useful lens through which to see the racio-cultural identity development of Black people within a broader social context. However, despite its useful theoretical tenets about Black identity, this model has been criticized for its linear stages of progression that does not provide opportunities for flexibility in one's identity development within the reconstruction process (Branch \& Young, 2006). In this article, reconstruction is understood as an ongoing developmental process of cultural identity where an immigrant redevelops and renegotiates a new identity based on their spatial and temporal locations (Hall, 1996, 1997). Cross's (1971, 1978) model, however, appears to place less focus on the reconstruction of the salient spiritual and religious aspects of Black people's cultural identities that signify sources of strength and resilience (Dixon, 2015).

Despite its limitations, Cross's (1978) model has broader multicultural applications for understanding how individuals' function in community, family and socio-cultural settings (Moodley, 2007; Sue et al., 1996). This model provides insight into racial socialization and Black identity development. It is adaptable to the cultural identity reconstruction of JCIW whose identity becomes fragmented as a result of post-migration societal stressors, which impact their social determinants of health (Raphael, 2016). According to the Government of Canada (2018), social determinants of health denotes a specific group of socio-economic issues within the broader determinants of health; these issues apply to one's place in society, such as income, education or employment. Also, experiences of discrimination, racism, historical trauma from the intergenerational and psychological impact of slavery are also important social determinants of health for certain groups, such as JCIW (Understanding Slavery Initiative, 2011). The women in this study, in question, found resiliency through their spiritual faith as they continued to wrestle with finding a sense of belonging in Canada, no longer as caged birds but free birds with hopes of better days. 


\section{Spiritual Resiliency and Pentecostal Faith}

Across the diasporas, spirituality is often viewed as a universal concept that holds subjective meaning for diverse individuals and cultural groups (Yusuf, 2010). In this discussion, spirituality refers to a more personal and dynamic experience of the sacred (Moodley \& Barnes, 2015). Within the Canadian context, it has been reported that approximately 22.1 million people, two-thirds of Canada's population, are affiliated with a Christian religion (Statistics Canada, 2013). In Canada, most Black Caribbean immigrants (79\%) identify with the Christian faith (Statistics Canada, 2007b). The top ancestral origins among Blacks in Canada are Caribbean and African such as Jamaicans (22.8\%), Haitians (13.9\%), Somalians (4.4\%) and Trinidadians/ Tobagonians (3.7\%) (Statistics Canada, 2007a). Many Jamaicans living in Canada report that they belong to a Christian religious denomination. According to Statistics Canada (2007a, 2007b), approximately over half (52\%) of all Jamaicans in Canada reported that they belonged to a mainline Protestant denomination, while $18 \%$ said they were Catholic and a further $12 \%$ said they belonged to another Christian grouping.

For many JCIW, post-migration stressors are major contributors to their personal experiences of social marginalization. These experiences can result in racial and cultural discrimination, which are likely to have fragmented their collective sense of self (Dixon, 2016). Despite this fragmentation, the spiritual fervor that JCIW gain from their Pentecostal faith serves as a mobilizing force that pushes them toward the unknown wherein lies their "graves of dreams" (Angelou, 1979, 5th stanza).

Here I draw attention to the Pentecostal movement, which is said to have originated in the US in the 1900s (Schwarz, 2005; Wilkinson \& Althouse, 2010). With a growing number of over 524 million believers (i.e., $25 \%$ of the Christians worldwide), it has become a propelling force in Christianity in the last hundred years (Cox, 2009; Schwarz, 2005). The term believer is often used in the Pentecostal denomination to refer to adherents of the faith (Bruner, 1977). Pentecostals are called such because the first sign of the Spirit was evident on the Day of Pentecost after Jesus's death in the Christian faith tradition (see Acts 2:1-4, New King James Version [NKJV]). Arguably, a key reason for the ongoing explosion of the Pentecostal movement is that for many, it offers them a more experiential faith experience like speaking in tongues and charismatic worship (Schwarz, 2005). Speaking in tongues (aka prayer language or glossolalia), in this discussion, is understood as an "ecstatic worship or prayer using unintelligible speech that is considered a gift of the Holy Spirit" (Pew Research Centre, 2006, para. 13). In addition to glossolalia, charismatic worship is a common practice within the Pentecostal faith tradition (Dixon \& Arthur, 2014). To illustrate, many Black Pentecostal churches have developed a distinct charismatic style of praise and worship through singing that preserved many elements of African-style rituals (Reed, 2012). Further, in modern Caribbean cultures, drumming and certain types of rhythms are still vital to the worship practices of JCIW who practice Pentecostal faith (Toulis, 1997). I would posit that these forms of charismatic practices (i.e., charismatic dancing, worship songs, etc.) provided a sense of freedom to the coresearchers whose faith uplifted them from being caged birds to singing spiritual songs, which gave them a sense of cultural freedom in the Canadian space. This sense of freedom was displayed in the key sub-themes outlined in the research findings that are expanded on below.

Cultural and Pedagogical Inquiry, Summer 2020, 12(1), pp. 200-215

ISSN 1916-3460 () 2020 University of Alberta

http://ejournals.library.ualberta.ca/index.php/cpi/index 


\section{Relevant Research Findings}

In the study, 14 sub-themes ${ }^{6}$ were generated. However, for the purpose of this paper, three sub-themes will be focused on as they strongly reflect the underlying messages of captivity in social norms, feelings of sorrow, racial discrimination, social construction of identity, hope, strength, and survival echoed in Maya Angelou's (1979) iconic poem: I know why the caged bird sings. These sub-themes include: (i) the conversion process, (ii) joining and contributing to a built-in community, and (iii) the importance of story-sharing. Through the heart-felt stories outlined in these sub-themes, in conjunction with my own lived experiences, the co-researchers explained how they showed resiliency through their Pentecostal faith to navigate their postmigration challenges. What follows are the sub-themes that are written with the integration of my own self-reflections.

\section{Conversion}

A key sub-theme that emerged from the results was the conversion process to the Pentecostal faith. Conversion, in this space, represents a personal decision that is based on one's own spiritual conviction and not persuasion. That said, the conversion experiences had similar threads. All the co-researchers involved in the study also indicated that they were believers prior to relocating to Canada. A critical aspect of their conversion stories was that they embraced a more conservative lifestyle which was encouraged in their church communities. It is important to note that for all the participants' conversion occurred pre-migration. It played an integral role in how they reconstructed their cultural identity post-migration. All the participants related stories about their conversions into the Pentecostal faith, which aligned with their lifestyle changes. One of the scriptures in the Bible that guided the JCIW's spiritual transformation was Romans 12:2 (NKJV). It states: "And do not be conformed to this world, but be transformed by the renewing [emphasis added] of your mind, that you may prove what $i$ s that good and acceptable and perfect will of God." Two extracts from the co-researchers' narratives, highlighted their conversion experiences:

Faye (29 years old) explained: After the age of 14, you know my grandmother suddenly said I have to give my life to God, you know she explained everything to me. The reason why I should surrender was because I'm responsible for my own sins [emphasis added] and if anything happened to me I have to give an account for my life [emphasis added], and that's where my conversion started from. I got baptized when I was 16 years old (Dixon, 2015, p. 102).

Andrea (53 years old) discussed her experience: My father was Baptist and my mother was a Pentecostal... at age 16, I just made a personal decision [emphasis added]. I was born into a Christian family, but I developed a deeper relationship in the Pentecostal faith. I wanted to have a more personal relationship [emphasis added] with God and I choose to do that in the Pentecostal faith. I wanted to have my own experience with God (Dixon, 2015, p. 102).

\footnotetext{
${ }^{6}$ Please refer to my dissertation (Dixon, 2015) for a comprehensive discussion of the research methodology, analysis of findings, and generated results.

Cultural and Pedagogical Inquiry, Summer 2020, 12(1), pp. 200-215

ISSN 1916-3460 @ 2020 University of Alberta

http://ejournals.library.ualberta.ca/index.php/cpi/index
} 
The two co-researchers stated, that conversion signified a personal experience for them as they deepened their spiritual knowledge. According to them, their faith offered them a new perspective as immigrants to make meaning of their settings as they acculturated into a new socio-cultural context (Berry, 2005). In this discussion, acculturation describes "the process of internalizing the values, beliefs, and traditions of the larger society" (Sue \& Sue, 2016, p. 766). The acculturation experiences of the JCIW were evident in their interviews. They transitioned across history, time, and space through the resiliency of their faith (DePass, 2012a; Hall, 1996, 1997). Post-migration, the JCIW expressed that due to acculturation pressures they reconstructed their cultural identities to adapt a more liberal way of thinking, both inside and outside of the church community. For instance, one of the co-researchers talked about the need to reconstruct her pre-migration cultural identity, in terms of her dress code, as a way to fit in at school and at church. She said she started to wear pants, accessories and make-up which were forbidden in her Jamaican Pentecostal church. Changing her dress code helped her to assimilate within the Canadian culture and gave her a sense of belonging as she navigated social norms (Dixon, 2015). I suggest that with the sense of belonging, it is likely that the co-researcher became a free bird.

\section{Having a Built-in Community}

Having a Built-in Community was another important sub-theme that arose from the stories of the JCIW. It helped them cope with post-migration stressors such as systemic racism, stereotypes, discrimination, educational setbacks, financial challenges, and micro-aggressions. This sub-theme describes the significance of the Black church and its role in the lives of the coresearchers. For many of the JCIW, the church represents a sense of hope and joy. Indeed, a feeling of coming home. The church provides visionary, inspirational and positive contributions toward their moral and spiritual development (Dixon, 2015). The church's structure creates a space for a built-in community where women feel safe and have the freedom to play an active role in such church ministry activities like praise and worship, prayer groups, singing on the choir, and so forth (Toulis, 1997). Some of the narratives that the co-researchers shared, indicate their ongoing spirit of survival in Canada. The women drew their communal strength from the scripture, specifically Hebrews 10:25 (NKJV), which essentially states that believers should not forsake the assembly of the brethren but should exhort one another. The women shared similar experiences that church attendance in Canada played a pivotal part in their changing cultural identity because of positive social interactions with other members. For the JCIW, the spiritual anchoring of the church "provided them with a spiritual home away from home" (Dixon, 2015, p. 104).

Rosemarie (48 years old) said, for example: “... going to church has provided me with the spiritual support that I needed to cope with life in another culture after leaving Jamaica" (Dixon, 2015, p. 104). In Carol's (50+ years old) words: “. . when we go to the place of gathering, church, we are engaged in it" (Dixon, 2015, p. 104).

Andrea (53 years old) stated that without the support of the church community she would not have acculturated so well to her Canadian environment (Dixon, 2015).

The stories of the JCIW reinforce the fact that the built-in community that the church creates within the dominant Canadian culture, fosters wellness, newness and upliftment. The church continues to be a beacon of hope for many women in the Jamaican Canadian community as well as in the diaspora (Toulis, 1997). For example, the church leaders, a growing number of

Cultural and Pedagogical Inquiry, Summer 2020, 12(1), pp. 200-215

ISSN 1916-3460 @ 2020 University of Alberta

http://ejournals.library.ualberta.ca/index.php/cpi/index 
whom are women, have begun to recognize their socio-political and spiritual influences in the church and larger community. They provide constructive interventions through leadership conferences, crusades, praise and worship, prayer meetings, workshops, coaching sessions, counselling, motivational speaking, and teachings, in order to improve the quality of life for all people, irrespective of gender and race (Boudewijnse, 1998; Shirer, 2011). I suggest that being part of a built-in community and the opportunities for active participation and leadership is another important way in which these co-researchers who might be perceived as former caged birds, based on their post-migration struggles, can become free birds.

\section{Story-Sharing}

Based on the research finding, Story-sharing is the final sub-theme to be addressed in this paper that captures aspects of Maya Angelou's poem (1979). Great emphasis is placed on sharing co-researchers' stories about their post-migration lived experiences. Storytelling in African and Caribbean cultures is a unique practice that helps to preserve the community's history and traditions (Caribya, n.d). Such a traditional practice offers guidelines for living and explains how to overcome oppression and discrimination. For centuries, the artistic nature of storytelling has played a crucial role in fostering the resiliency of many African enslaved people in the Caribbean and has continued throughout the generations (Corsbie, 1991; Creighton, 2009). Sharing and listening to stories has given the art of storytelling unfathomable power in the African and Caribbean culture as people tell stories to construct their own identities (Corsbie, 1991; Creighton, 2009). Thus, the co-researchers emphasized that storytelling offered spiritual connections that fostered their resiliency to life stressors like racism, marginalization, discrimination and stereotypes in Canada (Dixon, 2015). Specifically Galatians 6:2 (NKJV), which indicates that they should bear each other's burdens, resonated with them.

The creative art of storytelling can be normalizing. As such, sharing and testifying offers the women a sense of connection and empathy for each other's lived experiences in coping and surviving post-migration challenges. For example, Kay expressed that "story-sharing provides encouragement for other believers" in the form of testimonies (Dixon, 2015, p. 106). As believers filled with passion and hope for a better tomorrow in the Canadian sphere, the JCIW were able to push themselves beyond their testimonial circles and engage their larger communities through story-sharing. Likewise, Princess Warrior indicated that sharing her faith with others was a great opportunity for her to form meaningful relationships in Canada (Dixon, 2015, 2016). The women's lived experiences attest to their faith, openness, and willingness to share their vulnerability, their abilities to shape each other's realities, and to establish trust within the dominant Canadian culture that is systemically saturated with stressors such as racism, discrimination, and gender stereotypes (DePass, 2012a; Dixon, 2019a; Taylor \& Richards, 2019). Once again, by sharing their stories and voicing their experiences, the women sang as free birds. This sense of freedom reduced the co-researchers' fears and gave them the agency to be heard in a meaningful and purposeful way. Hence, the need for this exploratory research that challenges the status quo of mainstream society that tends to downplay the saliency of faith as a protective coping tool for immigrant groups like JCIW.

Despite the scarcity of research of this nature in Canada, the thought-provoking discussions generated from this study around conversion, a built-in community and story-sharing should not be ignored, considering the need for such multicultural dialogues on faith in academic arenas like the social sciences. The lack of representation of these spiritually infused stories in

Cultural and Pedagogical Inquiry, Summer 2020, 12(1), pp. 200-215

ISSN 1916-3460 @ 2020 University of Alberta

http://ejournals.library.ualberta.ca/index.php/cpi/index 
various mainstream spaces adds credence to the argument that Black communities are still silenced and oppressed like caged birds. In the subsequent discussion, I address this state of oppression for Black immigrant women such as JCIW of faith in my study.

\section{Discussion}

For this section, I revisit the Cross's (1971) cultural identity model that was summarized earlier, in the literature review. I will draw parallels between key stages of the model and the above findings for a richer discussion. In reviewing Cross's model, I would argue that the Internalization stage and key identities affiliated with this stage hold much value for the cultural identity experiences of JCIW. For instance, the JCIW were able to embrace a Black nationalist identity by relying strongly on their faith for empowerment; to be able to take a stand and be heard with and outside of the church community. Further, by adapting a biculturalist identity mentality, the JCIW learned through the application of their faith practices to accept themselves and their pluralist perspectives of culture that include other salient dimensions, like gender and race. More so, the co-researchers arguably grew more comfortable with intersectionality of their multi-culturalist identity that speaks to their lived experiences as JCIW of the Pentecostal faith. In this view, I emphasize the argument that the changes experienced by the co-researchers are not linear, or lock step. Rather, the same individuals can move along and demonstrate different characteristics of their identities at different times. For example, experiencing racism may make one anti-white. But having positive experiences in the church can balance the negative experiences and encourage acceptance and love of the other/white people.

Reflecting on the lived experiences of JCIW, a key point of discussion are issues of oppression in the form of racism and discrimination. Within the context of the central subthemes explored above the JCIW, in this study, reported experiences of systemic racism and discrimination, particularly in their places of employment and educational institutions (Dixon, 2015). For example, the women stated that their academic achievements were devalued in the Canadian workplace. Such devaluation has significantly impacted their ability to find gainful employment (Alberta Network of Immigrant Women, 2000, 2006; Government of Alberta, 2010, 2015). Their experiences contradict research evaluating data from Statistics Canada's Longitudinal Immigration Database (IMDB) that showed that immigrants report higher rates of University degrees (49.7\%) than their Canadian-born counterparts (31\%) (Statistics Canada, 2018b).

Another staggering fact to consider in this discussion, is that compared to the Canadianborn population who had an employment rate of $84.0 \%$ in 2017 , employment rates for Canadian immigrants were $78.9 \%$ (Statistics Canada, 2018b). Given their stories, the domains of oppression are multifaceted in terms of how it negatively impacts the multiple identities of the co-researchers. This impact could either keep them caged in self-hate or liberated in self-love. However, in these oppressive circumstances of employment income disparities and other systemic obstacles (Picot \& Lu, 2017), their faith has given them hope, resiliency and the spirit to face life. The JCIW turn to their religious practices, like prayers and sharing their stories, in order to help them find meaning and purpose in their life struggles (Dixon, 2018a). 


\section{Conclusion}

The absence of inclusive discourse that speaks to the everyday lived experiences of faith amongst Caribbean immigrants like the JCIW warrants greater attention in the social science literature. The paucity of research on this population both within and outside of the Canadian context is an area of concern. This matter calls for scholars across the diasporas to conduct research that focuses on faith and its link to the oppressed intersectional identities of JCIW. Other investigations are also needed to look into the psycho-social well-being of this group, and how faith, working in tandem with their cultural identities, can help to generate a liberated sense of self as free birds with faith-based practices to cope with oppressive socio-economic forces. It is also important for social science scholars to work collaboratively to bring attention to the silent voices of JCIW. This would be a move in the right direction of freedom.

\section{References}

Alberta Network of Immigrant Women. (2000). Over-qualified, underemployed: Accessibility barriers to accreditation for immigrant women with foreign qualifications. https://www.aniw.org/about-us/aniw-research/

Alberta Network of Immigrant Women. (2006). Equitable treatment of immigrant/visible minority women as employees and volunteers in the Alberta voluntary sector. https://www.aniw.org/about-us/aniw-research/

Angelou, M. (1979). I know why the caged bird sings. Random House.

Arthur, N., \& Collins, S. (Eds.). (2010). Culture-infused counselling (2 ${ }^{\text {nd }}$ ed.). Counselling Concepts.

Berry, J. W. (2005). Acculturation: Living successfully in two cultures. International Journal of Intercultural Relations, 29(6), 697-712. https://doi.org/10.1016/j.ijintrel.2005.07.013

Boudewijnse, H. B. (1998). A farewell to Mary? Women, Pentecostal faith, and the Roman Catholic church on Curaçao, N. A. In H. B. Boudewijnse, A. F. Droogers \& F. H. Kamsteeg (Eds.), More than opium: An anthropological approach to Latin American and Caribbean Pentecostal Praxis (Vol. 14). The Scarecrow Press.

Branch, A., \& Young, R. (2006). Ethnic identity development of African Americans: Experiences in search of a paradigm. Western Journal of Black Studies, 30(3), 160. http://gateway.proquest.com/openurl/openurl?ctx_ver=Z39.88-2003\&xri:pqil:res_ ver $=0.2 \&$ res_id=xri:lion-us\&rft_id=xri:lion:rec:abell:R04273023

Bruner, F. D. (1997). A theology of the Holy Spirit: The Pentecostal experience and the New Testament witness (Reprint ed.). Wipf \& Stock Publisher.

Burr, V. (2003). Social constructionism (2 ${ }^{\text {nd }}$ ed.). Routledge.

Caribya. (n.d.). Literature. https://justwatch-hd.biz/episodes/bates-motel-season-3-episode-4/

Casas, J. M., \& Pytluk, S. D. (1995). Hispanic identity development: Implications for research and practice. In J. G. Ponterotto, J. M. Casas, L. A. Suzuki \& C. M. Alexander (Eds.), Handbook of multicultural counseling (pp. 155-180). Sage.

Cultural and Pedagogical Inquiry, Summer 2020, 12(1), pp. 200-215

ISSN 1916-3460 @ 2020 University of Alberta

http://ejournals.library.ualberta.ca/index.php/cpi/index 
Corsbie, K. (1994). Telling tales: Caribbean storytelling. https://www.caribbean-beat.com/issue-

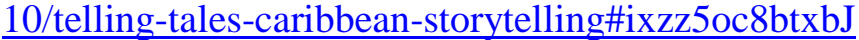

Cox, H. (2009). Fire from heaven: The rise of Pentecostal spirituality and the reshaping of religion in the 21 st century. http://public.eblib.com/EBLPublic/PublicView.do?ptiID=904318

Creighton, A. (2009). The African story-telling tradition in the Caribbean. https://www.stabroeknews.com/2009/sunday/arts-on-sunday/08/16/the-african-story-tellingtradition-in-the-caribbean/

Cross, W. E. (1978). The Thomas and Cross models of psychological nigrescence: A review. Journal of Black Psychology, 5(1), 13-31. https://doi.org/10.1177/009579847800500102

Cross, W. E. (1971). Toward a psychology of Black liberation: The Negro-to-Black conversion experience. Black World, 20(9), 13-27. http://eric.ed.gov/?q=Toward+a+psychology+of+Black+liberation\%3A+The+Negro-toBlack+conversion+experience

Cross, W. E., Parham, T. A., \& Helms, J. E. (1991). The stages of Black identity development: Nigrescence models. In R. L. Jones (Ed.), Black Psychology ( $3^{\text {rd }}$ ed., pp. 319-338). Cobb \& Henry.

DePass, C. (2012a). "Come mek we wheel and tun gal [... Come and dance with me...]". Snapshots of life in Jamaica and Calgary. In C. James \& A. Davis (Eds.), Jamaica in the Canadian experience: A multiculturalizing presence (pp. 208-217). Fernwood Publishing.

DePass, C. (2012b). 'Freedom songs' in selected Caribbean-Canadian contexts: Retrospective fragments. Journal of Contemporary Issues in Education, 7(1), 64-78. http://ejournals.library.ualberta.ca/index.php/JCIE/article/view/18075/14242

Dixon, S. (2015). Reconstructing cultural identities: The lived experiences of Jamaican Canadian immigrant women of Pentecostal faith (Unpublished Dissertation). University of Calgary, Calgary, Alberta, Canada.

Dixon, S. (2016). Making meaning of religious and spiritual cultural identities as a multicultural counsellor. COGNICA: The Canadian Counselling and Psychotherapy Association, 48(4), 10-13. https://www.ccpa-accp.ca/

Dixon, S. (2018a). Psycho-religious coping and immigrants. In D. A. Leeming (Ed.), Encyclopedia of Psychology and Religion (pp. 1-4). Springer Berlin Heidelberg. doi:10.1007/978-3-642-27771-9_200219-1

Dixon, S. (2019a). Intersectionality of cultural identities in health psychology: Key recommendations for working with African-Caribbean immigrant women. Frontiers in Sociology, 4(51), 1-14. https://doi.org/10.3389/fsoc.2019.00051

Dixon, S. (2019b). The relevance of spirituality to cultural identity reconstruction for African-Caribbean immigrant women. In N. Arthur (Ed.), Counseling in cultural context - Identity and social justice (pp. 249-270). Springer Science+Business Media Publishing. https://doi.org/10.1007/978-3-030-00090-5_11

Dixon, S., \& Arthur, N. (2019). Recognizing faith: A perspective on Black Caribbean Immigrant women. Canadian Journal of Counselling and Psychotherapy, 53(2), 169-197.

https://cjc-rcc.ucalgary.ca/article/view/61226/pdf

Cultural and Pedagogical Inquiry, Summer 2020, 12(1), pp. 200-215

ISSN 1916-3460 () 2020 University of Alberta

http://ejournals.library.ualberta.ca/index.php/cpi/index 
Dixon, S., \& Arthur, N. (2014). Creating space to engage Black Pentecostal clients in multicultural counselling practices. International Journal for the Advancement of Counselling, 37(2), 93104. https://doi.org/10.1007/s10447-014-9228-x

Edwards, D., \& Potter, J. (1992). Discursive psychology. Sage.

Este, D., Lorenzetti, L., \& Sato, C. (Eds.). (2018). Racism and anti-racism in Canada. Fernwood Publishing.

Government of Alberta. (2010). What works?: Career-building strategies for people from diverse groups. Government of Alberta. https://alis.alberta.ca/media/2124/ww cover.pdf

Government of Alberta. (2015). Alberta labour force profiles: The changing profile of Alberta's labour force. http://work.alberta.ca/labour/labour-force-profiles.html

Government of Canada. (2018, September 25). Social determinants of health and health inequalities. https://www.canada.ca/en/public-health/services/health-promotion/population-health/whatdetermines-health.html

Hall, S. (1992). The question of cultural identity. In S. Hall, D. Held \& A. McGrew (Eds.), Modernity and its futures (Vol. IV, pp. 273-280). Polity Press.

Hall, S. (1996). 'Who needs identity?' In S. Hall \& P. du Gay (Eds.), Questions of cultural identity (pp. 1-17). Sage.

Hall, S. (1997). Old and new identities: Old and new ethnicities. In A. D. King (Ed.), Culture, globalisation and the world-system: Contemporary conditions for the representation of identity (pp. 41-68). University of Minnesota Press.

Hiles, D. (2008). Heuristic inquiry. In L. M. Given (Ed.), The Sage encyclopedia of qualitative research methods (pp. 390-393). Sage.

James, C. E. (Ed.) (2010). Seeing ourselves: Exploring race, ethnicity and culture (4th ed.). Thompson Educational Publication.

James, C. E., \& Davis, A. (Eds.). (2012). Jamaica in the Canadian experience. Fernwood Publishing.

Jones, F., Fearon, A., \& Hendrickson, M. (2014). Implementation of the Cairo programme of action in the Caribbean (1994-2013): Evaluating progress and renewing commitment. United Nations Studies and Perspectives Series. http://repositorio.cepal.org/bitstream/handle/11362/37207/1/S131075 en.pdf

McKenzie, K., Khenti, A., \& Vidal, C. (2011). Cognitive-behavioural therapy for English-speaking people of Caribbean origin: A manual for enhancing the effectiveness of CBT for Englishspeaking people of Caribbean origin in Canada. Centre for Addiction and Mental Health (CAMH).

Moodley, R. (2007). (Re)placing multiculturalism in counselling and psychotherapy. British Journal of Guidance \& Counselling, 35(1), 1-22. https://doi.org/10.1080/03069880601106740

Moodley, R., \& Barnes, C. (2015). Multiculturalism, religion and counselling: Freedom to heal. In G. Nolan \& W. West (Eds.), Therapy, culture and spirituality: Developing therapeutic practice (pp. 7-23). Palgrave Macmillan.

Cultural and Pedagogical Inquiry, Summer 2020, 12(1), pp. 200-215

ISSN 1916-3460 () 2020 University of Alberta

http://ejournals.library.ualberta.ca/index.php/cpi/index 
Moodley, R., Shipton, G., \& Falken, G. (2000). The right to be desperate and hurt and anger in the presence of Carl Rogers: A racial/psychological identity approach. Counselling Psychology Quarterly, 13(4), 353-364. https://doi.org/10.1080/713658498

Moustakas, C. E. (1990). Heuristic research: Design, methodology, and applications. Sage.

Othering 101 Psychology. (2011). Othering 101: What is "othering”? https://therearenoothers.wordpress.com/2011/12/28/othering-101-what-is-othering/

Owen, J., Tao, K. W., Imel, Z. E., Wampold, B. E., \& Rodolfa, E. (2014). Addressing racial and ethnic microaggressions in therapy. Professional Psychology: Research and Practice, 45(4), 283-290. http://dx.doi.org/10.1037/a0037420

Pew Research Center. (2006, October 5). Spirit and power - a 10 country survey of Pentecostals: Glossary of Terms. http://www.pewforum.org/2006/10/05/spirit-and-power-a-10-countrysurvey-of-pentecostals2/

Picot, W. G., \& Lu, Y. (2017). Chronic low income among immigrants in Canada and its communities. Statistics Canada.

Raphael, D. (Ed.) (2016). Social determinants of health: Canadian perspectives ( $3^{\text {rd }}$ ed.). Canadian Scholars' Press Incorporated.

Reed, T. L. (2012). Shared possessions: Black Pentecostals, Afro-Caribbeans, and sacred music. Black Music Research Journal, 32(1), 5-25. https://www.jstor.org/stable/10.5406/blacmusiresej.32.1.0005

Richardson, T. Q., Bethea, A. R., Hayling, C. C., \& William-Yaylor, C. (2010). African and AfroCaribbean American identity development. In J. G. Ponterotto, J. M. Casas, L. A. Suzuki \& C. M. Alexander (Eds.), Handbook of Multicultural Counselling ( $3^{\text {rd }}$ ed., pp. 227-239). Sage.

Schwarz , J. (2005). Living faith: A guide to the Christian life. Baker Books.

Sela-Smith, S. (2002). Heuristic research: A review and critique of Moustakas's method. Journal of Humanistic Psychology, 42(3), 53-88. https://doi.org/10.1177/0022167802423004

Shirer, P. (2011). The resolution for women. B \& H Publishing Group.

Shotter, J. (1993). Conversational realities: Constructing life through language. Sage

Statistics Canada. (2007a). The Caribbean community in Canada. http://www.statcan.gc.ca/pub/89-621-x/89-621-x2007007-eng.htm

Statistics Canada. (2007b). The Jamaican community in Canada. https://www150.statcan.gc.ca/n1/pub/89-621-x/89-621-x2007012-eng.htm

Statistics Canada. (2013). 2011 National household survey: Data tables. Retrieved from: https://www12.statcan.gc.ca/nhs-enm/2011/dp-pd/dt-td/Index-eng.cfm

Statistics Canada. (2017). Census profile: 2016 census. https://www12.statcan.gc.ca/census-recensement/2016/dp$\mathrm{pd} /$ prof/details/page.cfm?Lang $=\mathrm{E} \& \mathrm{Geo} 1=\mathrm{CSD} \& \mathrm{Geo} 2=\mathrm{PR} \& \mathrm{Code} 2=01 \&$ SearchType $=$ Begins $\underline{\& S e a r c h P R}=01 \&$ TABID $=1 \& \mathrm{~B} 1=\mathrm{All} \&$ type $=0 \&$ Code $1=4806016 \&$ SearchText $=$ calgary

Cultural and Pedagogical Inquiry, Summer 2020, 12(1), pp. 200-215

ISSN 1916-3460 @ 2020 University of Alberta

http://ejournals.library.ualberta.ca/index.php/cpi/index 
Statistics Canada. (2018a). Immigrant and ethnocultural diversity in Canada. https://www12.statcan.gc.ca/nhs-enm/2011/as-sa/99-010-x/99-010-x2011001-eng.cfm

Statistics Canada (2018b). The immigrant labour force analysis series. The Canadian immigrant labour market: Recent trends from 2006 to 2017. https://www150.statcan.gc.ca/n1/pub/71-606-x/71-606-x2018001-eng.htm

Statistics Canada. (2019). Diversity of the Black population in Canada: An overview. https://www150.statcan.gc.ca/n1/en/pub/89-657-x/89-657-x2019002-eng.pdf?st=2qIrkmjt

Sue, D. W., Ivey, A. E., \& Pedersen, P. B. (1996). A theory of multicultural counseling and therapy. Brooks/Cole Publishing Corporation.

Sue, D. W., \& Sue, D. (2016). Counseling the culturally different: Theory and practice ( th $^{\text {ed.). Wiley. }}$

Sue, S., \& Sue, D. W. (1971). Chinese-American personality and mental health. Amerasia Journal, 1(2), 36-49. https://doi.org/10.17953/amer.1.2.n6680j28804v3g61

Sullivan, J. M., \& Esmail, A. (2012). African American identity: Racial and cultural dimensions of the Black experience. Lexington Books.

Taylor, R. J., Chatters, L. M., Mattis, J. S., \& Joe, S. (2010). Religious involvement among Caribbean Blacks residing in the United States. Review of Religious Research, 52(2), 125-145. Retrieved from: http://www.ncbi.nlm.nih.gov/pubmed/21927509

Taylor, D., \& Richards, D. (2019). Triple Jeopardy: Complexities of racism, sexism, and ageism on the experiences of mental health stigma among young Canadian Black women of Caribbean descent. Frontiers in Sociology, 4(43). doi:10.3389/fsoc.2019.00043

Toulis, N. R. (1997). Believing identity: Pentecostalism and the mediation of Jamaican ethnicity and gender in England. Berg.

Tulshyan, R. (2015, February 10). Speaking up as a woman of color. Forbes, 1-7. https://www.forbes.com/sites/ruchikatulshyan/2015/02/10/speaking-up-as-a-woman-ofcolor-at-work/\#1e5a03562ea3

Understanding Slavery Initiative. (2011). Diaspora. http://understandingslavery.com/index.phpoption=com_content $\&$ view=article $\&$ id=314\&Itemid=226.html

Walsh, F. (2003). Family resilience: A framework for clinical practice. Family Process, 42(1), 1-18. https://www.ncbi.nlm.nih.gov/pubmed/12698595

Wilkinson, M., \& Althouse, P. (Eds.). (2010). Winds from the north: Canadian contributions to the Pentecostal movement (Vol. 10). Brill.

Worldometer. (n.d). Caribbean populations. Retrieved May 12, 2020 from: https://www.worldometers.info/world-population/caribbean-population/

Yusuf, H. (2010). Spirituality, multiculturalism and anti-oppressive practice. In Building bridges for wellness in counselling and psychotherapy (pp. 367-376). Centre for Diversity in Counselling and Psychotherapy.

Cultural and Pedagogical Inquiry, Summer 2020, 12(1), pp. 200-215

ISSN 1916-3460 () 2020 University of Alberta

http://ejournals.library.ualberta.ca/index.php/cpi/index 